\title{
Aspects Regarding Prophylaxis of Scoliosis Attitudes by Specific Means of Basketball
}

\author{
Leonte Nicoleta ${ }^{1 *}$ \\ Popescu Ofelia ${ }^{2}$ \\ Pricop Adrian ${ }^{3}$ \\ Neagu Narcis ${ }^{4}$
}

1,2,3,4University Politehnica of Bucharest, Splaiul Independenței, 313, 060042, Romania

Keywords: prevention, postural attitudes, scoliosis, basketball

\begin{abstract}
This paper subscribes the efforts to promote youth health and the prevention of osteomusculo-articular disorders in their professional career. Physical exercise represents the central pillar in preventing the spine deficiency attitudes. Rendering efficient the prevention methods for the deficient postural attitudes requires an effort to anticipate the potential adverse effects of the new technologies on the health and safety of the young people. The paper's aim is to make known the diversification of the kinetic and prophylactic means and of those for recovering the light deficiency posture attitudes (scoliosis) by developing programs which use basketball means. Enriching the kinetic programs through various basketball means, constitutes a necessity for executing, developing and improving the normal motor functions, but also for the re-educating the deficient ones.
\end{abstract}

\section{Introduction}

Promoting youth health and the prophylaxis of the osteo-musculo-articular disorders throughout the working life, even starting with the first job is vital in allowing a long period of activity. Therefore, physical exercise and also the prophylaxis of the spine deficiency attitudes, contributes to combating the effects of the demographic aging in the long run, according to the Europe Strategy 2020 goals for an intelligent, sustainable growth and which is also favorable to the inclusion.

Rendering efficient the methods for the prevention of deficient postural attitudes requires an effort to anticipate the potential adverse effects of the new technologies on the health and safety of the young people.

According to a recent Eurobarometer survey young people believe that stress is one of the main occupational risks (53\%), followed by the ergonomic risks

\footnotetext{
*E-mail: nico_balbeck@yahoo.com;
} 
(repetitive movements or tiring and annoying positions, 28\%) and lifting, carrying or moving daily loads (24\%). Women, especially, face specific risks such as musculoskeletal disorders (scoliosis, lordosis, and kyphosis) due to the nature of certain professions in which they are over-represented.

According to a Health Ministry statistics, about half of the Romanian population suffers from diseases of the spine and 6 in 10 adults report suffering from more or less severe backaches.

Following the study conducted by Leonte and Popescu (2014) on a sample of the student population from the UPB we observed that vertebral statics disorders of the scoliosis type are present in $26.25 \%$, the kyphosis type ones are present in a proportion of $23.13 \%$ and the lordotic ones are present in $20.63 \%$ of the subjects investigated.

The mental state that is induced by practicing motor activities obliges us to search for solutions to attract students and raise their awareness on the benefits of the physical exercise and, in the same time, to choose means specific to sport branches (basketball) which should contribute to the diversification of the physical therapy programs.

\section{Material and methods}

The paper aims to contribute to the knowledge on the means associated to physical therapy so that the prevention / recovery programs for deficient postural attitudes be more diverse and attractive to students. This paper presents a new methodological approach of kinetoterapy programs by including the basketball specific means.

\section{Premise}

1. Risk prevention and promotion of safer and healthier conditions in the everyday and professional life are essential for improving the quality of life.

2. During the period of transition from adolescence to young adult spinal deformities often have causes related postural attitude defects.

3. Maintaining young people's good health has a direct, positive and measurable impact on the academic and professional performances.

The purpose is the introduction of basketball specific means in kinetoterapy programs, to diversify classics exercises for the prevention/ recovery poor attitudes (scoliosis) in young people.

Hypothesis. The fact that we know the main biomechanical characteristics of the throwing to basket, will recommend its inclusion in the prevention / recovery programs for the scoliosis postural attitudes.

The present paper is a preliminary study, which is part of a comprehensive research (GRANT - GEX) on "Evaluation of Movement through Computer Techniques for the Improvement and Diversification of Physical Therapy Programs by means of Basketball", supported by University Politehnica of Bucharest.

At this initial stage, we dealt with extensive documentation in order to know the vast and complex problem of the scoliosis attitudes as well as the biomechanics of basketball movement and we identified the main means of basketball with 
applicability in physical therapy, which through dynamism should contribute to raising the interest of the subjects (Students) in attending Physical Therapy classes, setting up the experimental and control group and making a commitment to the availability of subjects as volunteers.

In the future, it is desired to make the results more objective by including along with the plantar pressure assessment (PedarX), the computerized methods of motion analysis (VICON).

The subjects involved in this experiment are students of the Polytechnic University of Bucharest, who has folow the kinetoterapy courses. The sample consists of 10 students ( 4 girls and 6 boys) identified as having spine disorders (subjects suffer of thoracic scoliosis C), that proposed us to be volunteers in this study.

Location and duration. The research was conducted between October 2016 January 2017, within the Department of Physical Educatin and Sport-Kinetoterapy, Polytechnic University of Bucharest.

\section{The Main Characteristics of the Correct Body Attitude}

The normal and harmonious development of the body is based on its correct attitude, this being a sign of the physical and mental balance.

Duma, 1997 defines the correct attitude as that attitude favoring the normal movements and the correct movements, in turn, determine the attitude recovery. Thus, when doing exercises to correct the deficient attitudes we must always respect the principle of doing the exercises from the correct positions.

Pásztai, Cristea, and Cristea, (2010), believes that "the correct attitude of the body is ensured by a corresponding, synergistic and perfectly coordinated contraction of the antagonistic muscle groups. If the contraction function or the antagonist muscle tone is troubled, they will not be able to balance the opposing forces of the normal attitude and there will take place functional disorders of attitude that favors attitude deficiencies".

An important role in educating and maintaining the correct body attitude is played by the nervous system (central and peripheral). The specialized organs of the nervous system (the acoustic-vestibular analyzer, the visual analyzer) contribute to a "real sense of the attitude" (Balint, 2010).

Educating the body correct attitude is based on the connection between the attitude reflex formation (the self-control of the body posture and its segments) and the development of the muscle groups. Thus the attitude reflex cannot be maintained with a hypotonic musculature; on the other hand, a well-developed musculature does not provide a correct attitude of the body, without educating the attitude reflex.

The literature emphasizes the objectives for the development of the muscle groups that ensure the correct attitude body. These are the following:

- to tone symmetrically the abdominal and sacral lumbar muscles, which by their synergistic and coordinated tone ensure the pelvis stability and support the abdominal viscera;

- to tone when shortening the spinal muscles and the nape muscles; 
- to tone when shortening the adductors and the scapula fixators;

- to tone when lengthening the thoracic musculature;

- to maintain the mobility of the scapular-humeral and the hip-femur joints in order to increase the independence movement of the upper limb towards the shoulders and of the lower limbs towards the pelvis, thus combating the wrong tendency of the children to synchronize the movements of the shoulder girdle and the spine with the arms movements in the anterior plan and also those of the pelvic girdle and the pelvis with the lower limb movements in the posterior plan.

Scoliotic Attitude-Scoliosis

The specialists in the field (Moldovan, 2016) believe that scoliosis is a lateral, incompletely reducible deviation of the spine with progressive evolution and effects on its morphology and functionality.

According to Sbenghe, 1987, the plans in which there is scoliosis are the following: frontal, sagittal and horizontal (on a larger or smaller surface) with the vertebral bodies rotation so that the spinous apophyses of the vertebrae are rotated towards the concavity of the scoliosis and the vertebral bodies towards the convexity without losing the osteo-articular continuity.

While scoliosis is defined as a permanent deformation of the rachis, the scoliotic attitude is a problem of reversible statics without permanent lesions (Fig. 1).

This type of scoliosis is not accompanied by changes in the vertebral structure or gibbosity and reduces spontaneously or by minimal interventions.

The scoliosis attitude is not accompanied by a rotation of the vertebrae, but it often combines with the kypho-lordotic attitude. This situation is found in the case of rapid growth, musculo-ligamentous failure, poor spinal hygiene or sometimes unequal lower limbs with imbalance of the pelvis (a mechanical imbalance recovered by applying inserts).

The objectives proposed in correcting the scoliotic attitude, are the following:

- to develop the thorax symmetrically;

- to correct the spine and back deviations;

- to maintain in symmetrical position the shoulders, the scapula, the hips and the lower limbs;

- to develop the thorax elasticity;

- to prevent the apparition of a compensatory curvature in the superjacent or subjacent region. 


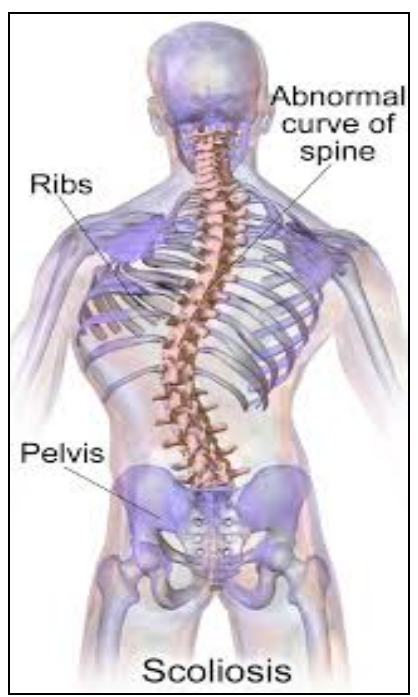

Figure 1. Scoliosis

(Wikipedia. (2015. July)

The specialists in the field refer to the muscular causes of the physiological curves changes and the special role of the balanced spine support.

Each kinematic chain consists of several muscle groups, thus becoming muscle chains. Since most human movements are complex movements, in doing them there are mobilized more muscle groups with antagonistic or synergistic action and kinematic couples.

For example, for the arm movement in throwing to basket with a hand on place, the kinematic chain consists of - the fingers flexors, wrist flexors, extensors of the elbow, arm anteductors, lifters and the muscles which basculate the scapula laterally.

\section{Results and Discussions}

For better understanding of how to use the basketball procedure in correcting a scoliotic attitude, we present the biomechanical analysis of shooting on place, with one hand overhead.

This procedure, of shooting on place, combines the static effort with the dynamic one (Fig. 2).

The static effort is made by the antagonistic muscles (the muscle chains of the lower limbs and torso by balancing effort) and by the muscles of the vertebral channels (the triple extension from the lower limbs).

The dynamic effort consists of the coordinated and dosed extension of the upper and lower limbs, the movement being provided by: the fingers flexors, wrist flexors, extensors of the elbow, arm anteductors, lifters and the muscles which basculate the scapula laterally. It is a defeat type movement; after shooting, the dynamic muscular effort changes in the dynamic activity of transfer, ensuring 
elastically the position and being at the same time, a basis for the movements that follow (Făgăraș, 2015).

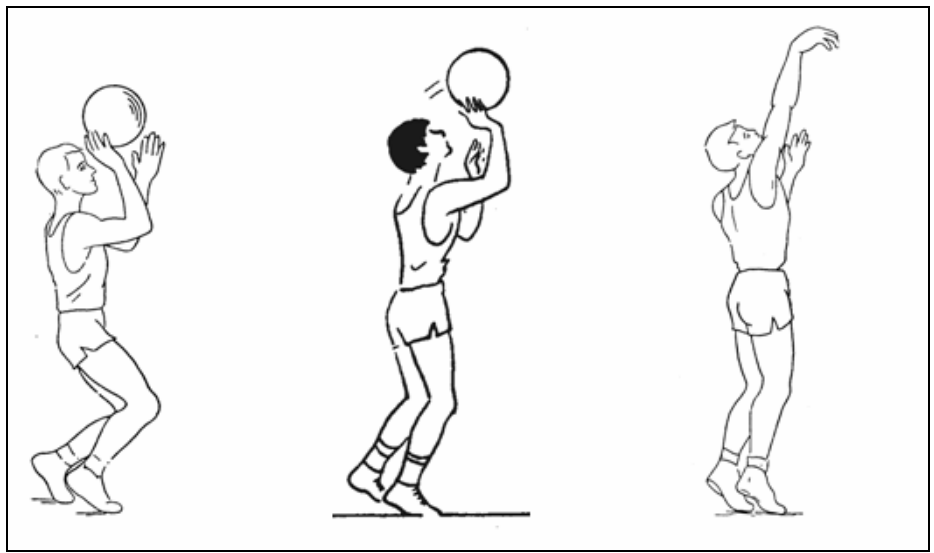

A.

B.

C.

Figure 2. A.The Initial Position; B. The Intermediary Position; C. The Final Position

Intervention program proposed for preventing/correcting the scoliotic attitudes and the scoliosis.

1. Standing on the right side of the basket $(1.5 \mathrm{~m})$, at an angle of $45^{\circ}$ towards the basket, knees slightly bent - extension at the lower limbs, concomitantly with shooting on place with the right hand.

2. Standing on the left side of the basket $(1.5 \mathrm{~m})$, at an angle of $45^{0}$ towards the basket, knees slightly bent - extension at the lower limbs, concomitantly with shooting on place with the left hand.

3. Standing on the right side of the basket $(1.5 \mathrm{~m})$, at an angle of $45^{0}$ towards the basket, the basketball is kept on the right hand, the left hand is bent to the back, and knees slightly bent - extension at the lower limbs, concomitantly with shooting on place with the right hand.

4. Standing on the left side of the basket $(1.5 \mathrm{~m})$, at an angle of $45^{0}$ towards the basket, the basketball is kept on the left hand, the right hand is bent to the back, and knees slightly bent - extension at the lower limbs, concomitantly with shooting on place with the right hand.

5. Standing on the right side of the basket $(1.5 \mathrm{~m})$, at an angle of $45^{\circ}$ towards the basket, the basketball is kept on the right hand, the left leg (on the convexity side) is bent and supported on a bench, the left hand is bent to the back, knees slightly bent - extension at the lower limbs, concomitantly with shooting on place with the right hand. 


\section{Discussions}

The lack of physical activity, technologization and the excessive use of computers by young people lead to the appearance of deficient postural attitudes. The most common ones among young people are scoliosis attitudes.

Practicing kinetic programs and raising awareness among young people with scoliosis attitudes are often difficult, with monotony interfering. This requires specialists in the field to diversify kinetic programs using associated means, such as those specific to some sports branches (basketball).

There are numerous studies attesting the influence of sports activities on scoliosis at different ages.

McMaster, Lee, and Burwell (2006) conducted a study to assess the physical activity of patients with progressive idiopathic scoliosis and compared the results with those of a control group. Following the study, it was noted that progressive idiopathic scoliosis is positively associated with swimming and negatively with participation in dancing, skating, gymnastics, karate and riding courses.

In European countries, there is a major preoccupation for early detection of deficient postural attitudes. Thus, in Russia, children with spine disorders are included in special classes of medical gymnastics. In Germany, two additional weekly hours are included to perform corrective exercises under the guidance of a physical therapist (Mitova, Popova \& Gramatikova, 2014)

Razumeiko (2015) believes that in order to ensure the early diagnosis and organization of preventive corrective measures, it is necessary to permanently monitor the physical condition and physical capacity of the young people.

Jandrić (2015) believes that sports which train unilateral and asymmetrical muscles, such as rowing, fencing, tennis and athletic disciplines (spear, hammer throwing), should be avoided. Sports activities and participation in physical education and sports classes are allowed to young people with scoliotic attitudes, coupled with the development of specific kinetic programs in order to prevent worsening of the deficient postural attitude.

Puzovic et al. (2015) say it is hard to say whether basketball can have a positive effect on scoliosis in children and teenagers, as there is little evidence that basketball means are beneficial in treating subjects with scoliotic attitudes.

The International Scientific Society on the treatment of scoliosis does not recommend sports activities for subjects diagnosed with idiopathic scoliosis. Instead, sports activities are recommended for any type of poor postural attitude due to their psychological, neuromuscular, and general health effects. (Jandrić, 2015)

The research mentioned does not completely solve the problem of prophylaxis and treatment of scoliosis through sports activities. Thus, it is necessary to continue the interdisciplinary research to find the best solutions for the prophylaxis of posture and alignment disorders.

We consider that this paper opens new research directions, with applicative value, by developing models based on the specific means of basketball, in order to improve the health of young people. 


\section{Conclusions}

The basketball techniques, seen as means associated to physical therapy represent an innovative approach to postural prevention.

Shooting on place is a fundamental technical element of basketball, which can be used successfully in kinetic programs.

The biomechanical description of scoliotic attitude elucidated the main aspects of the changes in the spine.

We found muscle tone asymmetry on the convexity and concavity of the malformation. The mobility of the paravertebral muscles of the concave side of the deformation is more reduced in comparison with the convex one. Also, as a result of the changes mentioned the rib cage shrinks vertically and increases horizontally.

Knowing the biomechanics of shooting with one hand on place, entitles us to believe that it can be included in the programs for the prevention / recovery of the scoliotic attitudes. Thus, in the case of a scoliotic attitude on the left side, by the triple extension movement of the lower limbs (the ankle joint, the knee joint and the hip-femoral joint) carried out simultaneously with the stretching the shooting arm, there is determined an increase of the suppleness (flexibility) in the paravertebral muscles on the concavity side (in their extension thereof) and a shortening of the paravertebral muscles on the convexity side.

Basketball, viewed as a means associated to physical therapy and practiced prophylactically has to be also doubled by other prophylactic measures: combating the sedentary lifestyle and promoting healthy diets.

\section{References}

1. BALINT, T. (2010). Kinetoprofilaxie. Curs studii de licență, Bacău: AlmaMater, 29;

2. DUMA, E. (1997). Deficiențele de dezvoltare fizică, Bucureşti: Argonaut;

3. FĂGĂRAŞ, P.S. (2015). Biomecanica aruncărilor la coș în jocul de baschet, Iași: Universității „Alexandru Ioan Cuza”;

4. JANDRIĆ, S. D., (2015). Scoliosis and sport, SportLogia Journal,11(1), 110 ;

5. LEONTE, N., \& POPESCU, O. (2014). The Importance of SomatosensoryFunctional Development in Preventing Posture Deficiencies among Students in Higher Technical Education, Procedia-Social and Behavioral Sciences, 117, 81-85;

6. McMASTER, M., LEE, A.J., \& BURWELL, R.G. (2006, May). Physical activities of patients with adolescent idiopathic scoliosis (AIS) compared with a control group: implications for etiology and possible prevention. In Orthopaedic Proceedings, 88, SUPP II: 225-225;

7. MITOVA, S., POPOVA, D., \& GRAMATIKOVA, M. (2014). Postural disorders and spinal deformities in children at primary school age. System for screening, examination, prevention and treatment. Activities in physical education and sport, 4 (2): 172-177; 
8. MOLDOVAN, K. (2016). Scoliozele copilului şi adolescentului, Medicină Şcolară şi Universitară, 2(3): 20-34;

9. PÁSZTAI, Z.C., CRISTEA, A., \& CRISTEA, D.I. (2010). The role of functional and proprioceptive kinetotheraphy in the prophylaxis of the ankleflat-foot complex-a case study, Palestrica mileniului III, 325;

10. PUZOVIC, V., ROTIM, K., JURISIC, V., SAMARDZIC, M., ZIVKOVIC, B., SAVIC, A., \& RASULIC, L. (2015). The Prevalence of Spine Deformities and Flat Feet among 10-12 Year Old Children Who Train Basketball-Cross-Sectional Study. Coll. Antropol, 39(3): 625-629;

11. RAZUMEIKO, N.S. (2015). Differentiated correction of junior school age children's posture at physical culture trainings. Pedagogics, psychology, medical-biological problems of physical training and sports, 19(11): 47-54;

12. SBENGHE, T. (1987). Kinetologie profilactică, terapeutică şi de recuperare, București: Medicală, 533-539;

13. WIKIPEDIA. (2015. July)./ https://ro.wikipedia.org/wiki/Scolioz\%C4\%83.

\title{
Aspecte privind Profilaxia Atitudinilor Scoliotice prin Mijloace Specifice J ocului de Baschet
}

\author{
Leonte Nicoleta ${ }^{1^{*}}$ \\ Popescu Ofelia ${ }^{2}$ \\ Pricop Adrian ${ }^{3}$ \\ Neagu Narcis 4 \\ 1,2,3,4Universitatea „Politehnică” din București, Splaiul Independenței, 313, 060042,
}

România

Cuvinte cheie: profilaxie, atitudini scoliotice, baschet

\section{Rezumat}

Prezenta lucrare se subscrie eforturilor de promovare a sănătății tinerilor și a profilaxiei afecțiunilor osteo-musculo-articulare, pe parcursul întregii vieți profesionale a acestora. Exercițiul fizic reprezintă stâlpul central al profilaxiei atitudinilor deficitare la nivelul coloanei vertebrale. Eficientizarea metodelor de prevenție a atitudinilor posturale deficitare necesită un efort de anticipare a potențialelor efecte negative ale noilor tehnologii asupra sănătății și siguranței tinerilor. Scopul lucrării este de a face cunoscută diversificarea mijloacelor kinetice profilactice și de recuperare a atitudinilor posturale deficitare ușoare (scolioza, lordoza) prin dezvoltarea unor programe folosind mijloacele din baschet. Îmbogăţirea programelor kinetice prin mijloace variate ale jocului de baschet, constituie o necesitate pentru exercitarea, dezvoltarea și perfecționarea funcțiilor motorii normale, dar şi pentru reeducarea celor deficitare. 


\section{Introducere}

Promovarea sănătății tinerilor și profilaxia afecțiunilor osteo-musculoarticulare pe parcursul întregii vieți profesionale, începând chiar cu primul loc de muncă, este vitală pentru a permite o perioadă de activitate cât mai lungă. Așadar, exerciţiul fizic, precum și profilaxia atitudinilor deficitare la nivelul coloanei vertebrale, contribuie la combaterea efectelor îmbătrânirii demografice pe termen lung, în conformitate cu obiectivele Strategiei Europa 2020 pentru o creștere inteligentă, durabilă și favorabilă incluziunii.

Eficientizarea metodelor de prevenție a atitudinilor posturale deficitare necesită un efort de anticipare a potențialelor efecte negative ale noilor tehnologii asupra sănătății și siguranței tinerilor.

Conform unui sondaj Eurobarometru recent, tinerii consideră că stresul este unul dintre principalele riscuri profesionale (53\%), urmat de riscurile ergonomice (mișcările repetitive sau pozițiile obositoare sau supărătoare, 28\%) și ridicarea, căratul sau deplasarea zilnică a greutăţilor (24\%). Îndeosebi femeile se confruntă cu riscuri specifice, cum ar fi afecțiunile musculo-scheletale (scolioze, lordoze, cifoze) din cauza naturii unor profesii în care sunt supra-reprezentate.

Potrivit unei statistici a Ministerului Sănătății, aproximativ jumătate din populația României suferă de afecțiuni ale coloanei vertebrale și 6 din 10 adulți acuză dureri de spate mai mult sau mai puțin severe.

În urma studiului efectuat de Leonte şi Popescu, (2014), pe un eșantion al populației studențești din cadrul U.P.B., s-a observat faptul că tulburările de statică vertebrală de tip scolioză sunt prezente la $26,25 \%$, cele de tip cifoză sunt prezente în proporție de 23,13\%, iar cele lordotice sunt prezente la 20,63\% din subiecții investigați.

Starea psihică pe care o induce practicarea activităților motrice ne obligă la căutări de soluții pentru atragerea și conștientizarea studenților privind beneficiile exercițiilor fizice și în același timp la alegerea mijloacelor specifice unor ramuri de sport (baschet) care să contribuie la diversificarea programelor de kinetoterapie.

\section{Material şi metode}

Lucrarea dorește să contribuie la îmbogăţirea cunoștințelor privind mijloacele asociate kinetoterapiei, astfel încât programele de prevenire/ recuperare a atitudinilor posturale deficitare să fie cât mai diversificate și atractive pentru studenți.

\section{Premise}

1. Prevenirea riscurilor şi promovarea unor condiții mai sigure şi mai sănătoase în viața cotidiană și profesională, sunt esențiale pentru îmbunătăţirea calității vieții.

2. În perioada de trecere de la adolescență la tineri adulţi, deformaţiile coloanei au, deseori, cauze care ţin de viciile de atitudine posturală.

3. Menținerea unei bune stări de sănătate a tinerilor are un impact pozitiv direct și măsurabil asupra performanțelor academice și profesionale. 
Scop. Introducerea în cadrul programelor kinetice a mijloacelor specifice baschetului, în scopul diversificării exercițiilor clasice pentru prevenirea/recuperarea atitudinii deficitare (scolioza) la tineri.

Ipoteza. Cunoașterea principalelor caracteristici biomecanice ale aruncării la coş de pe loc, va recomanda includerea acesteia în programele de prevenire/ recuperare a atitudinilor posturale scoliotice.

Lucrarea de față reprezintă un studiu preliminar, care face parte dintr-o cercetare amplă (GRANT - GEX) privind „Evaluarea mişcării prin tehnici computerizate în vederea perfecționării și diversificării programelor de kinetoterapie prin mijloace specifice jocului de baschet”, susținută de Universitatea Politehnica din București.

În această etapă iniţială s-a realizat o documentare amplă în scopul cunoaşterii problematicii vaste și complexe a atitudinilor scoliotice, a biomecanicii mișcării în baschet, s-au identificat principalele mijloace ale baschetului cu aplicativitate în kinetoterapie, care prin dinamism să contribuie la o creștere a interesului subiecților (studenților) în participarea la orele de kinetoterapie, constituirea grupului experimental și a celui de control, întocmirea unui angajament de disponibilitate privind participarea subiecților ca voluntari.

În perspectivă, se dorește obiectivizarea rezultatelor prin includerea alături de evaluarea presiunii plantare (PedarX) și a metodelor computerizate de analiză a mișcării (VICON).

Subiecții participanți în cadrul acestei cercetări sunt studenți ai Universităţii Politehnica București, care au urmat cursurile de kinetoterapie. Eșantionul va fi de 10 studenți (4 fete și 6 băieți), depistați cu atitudine scoliotică, care s-au oferit voluntari pentru prezentul studiu.

Locul și durata cercetării. Lucrarea de față prezintă o nouă abordare metodologică a programelor kinetice, prin includerea mijloacelor specifice jocului de baschet. Cercetarea s-a desfășurat în perioada octombrie 2016 - ianuarie 2017, în cadrul Departamentului de Educație Fizică și Sport-Kinetoterapie, Universitatea Politehnica București. Cercetarea se desfășoară conform schemei: pretest-aplicarea programelor kinetice-posttest.

\section{Principalele caracteristici ale atitudinii corporale corecte}

Dezvoltarea normală și armonioasă a corpului are la bază o atitudine corectă a acestuia, fiind un semn al echilibrului psihic și fizic.

Duma (1997), definește atitudinea corectă, acea atitudine care favorizează desfășurarea normală a mișcărilor, iar mișcările corecte, la rândul lor, determină o redresare a atitudinii. Astfel, efectuarea exercițiilor de corectare a atitudinilor deficiente trebuie să respecte întotdeauna principiul executării exercițiilor din poziții corecte.

Pásztai, Cristea, and Cristea (2010) sunt de părere că ,atitudinea corectă a corpului este asigurată de o contracţie corespunzătoare, sinergică şi perfect coordonată a grupelor musculare antagoniste. Dacă se tulbură funcţia de contracţie sau tonusul muşchilor antagonişti, aceștia nu vor putea echilibra forţele antagoniste 
ale atitudinii normale şi se vor produce tulburări funcţionale de atitudine, care favorizează viciile de atitudine."

Un rol important în educarea și păstrarea atitudinii corecte a corpului îl are sistemul nervos (central și periferic). Organele specializate ale sitemului nervos (analizatorul acustico-vestibular, analizatorul vizual) contribuie la formarea unui ,adevărat simț al atitudinii” (Balint, 2010).

Educarea atitudinii corecte a corpului are la bază conexiunea între formarea reflexului de atitudine (autocontrolul poziției corpului și a segmentelor sale) și dezvoltarea grupelor musculare. Astfel, reflexul de atitudine nu poate fi menținut cu o musculatură hipotonică; pe de altă parte, o musculatură bine dezvoltată nu asigură o atitudine corectă a corpului, fără educarea reflexului de atitudine.

Literatura de specialitate subliniază obiectivele pentru dezvoltarea grupelor musculare care asigură atitudinea corectă a corpului. Acestea sunt:

- tonifierea în mod simetric a musculaturii abdominale şi sacro-lombare, care prin tonusul lor sinergic şi coordonat, asigură stabilitatea bazinului şi susţinerea viscerelor abdominale;

- $\quad$ tonifierea în condiții de scurtare a muşchilor spinali şi a muşchilor cefei;

- tonifierea în condiții de scurtare a aductorilor şi a fixatorilor omoplaților;

- tonifierea în condiții de alungire a musculaturii toracice;

- menținerea mobilităților articulaţiilor scapulo-humerale şi coxo-femurale pentru a mări independența mişcărilor membrelor superioare față de umeri şi a membrelor inferioare faţă de bazin, combătând tendinţa greşita a copiilor de a solidariza mişcările centurii scapulare şi coloanei vertebrale cu mişcările brațelor în plan anterior precum şi cele ale centurii pelviene şi bazinului cu mişcările membrelor inferioare în plan posterior.

\section{Atitudine scoliotică - Scolioza}

Specialiștii domeniului (Moldovan, 2016) consideră că scolioza este o deviaţie laterală, incomplet reductibilă a coloanei vertebrale, cu evoluţie progresivă şi cu consecinţe asupra morfologiei şi functionalităţii acesteia.

După Sbenghe (1987), planurile în care se manifestă scolioza sunt: frontal, sagital si orizontal (pe o suprafaţă mai mare sau mai mică) cu rotaţia corpilor vertebrali, astfel încât apofizele spinoase ale vertebrelor sunt rotate spre concavitatea scoliozei, iar corpii vertebrali spre convexitate, fără pierderea continuităţii osteo-articulare.

În timp ce scolioza se defineşte ca o deformare permanentă a rahisului, atitudinea scoliotică este o problemă de statică reversibilă şi fără leziuni definitive (Fig. 1).

Acest tip de scolioze nu se însoţesc de modificări de structură vertebrală sau gibozitate şi se reduc spontan sau prin intervenţii minime.

Atitudinea scoliotică nu se însoţeşte de o rotaţie a vertebrelor, dar se combină frecvent cu atitudinea cifolordotică. Aceasta situaţie se întâlneşte în cazul unei creşteri rapide, insuficienţa musculo-ligamentară, igiena vertebrală deficitară sau, 
uneori, inegalitate de membre inferioare cu dezechilibru al bazinului (dezechilibru mecanic redresat prin aplicarea unui talonet).

Obiectivele propuse în corectarea atitudinii scoliotice, urmăresc:

- dezvoltarea simetrică a toracelui;

- corectarea deviațiilor coloanei vertebrale şi spatelui;

- menținerea în poziţie simetrică a umerilor şi omoplaților, şoldurilor şi membrelor inferioare;

- dezvoltarea elasticităţii toracelui;

- prevenirea instalării unei curburi compensatorii în regiunea supra sau subiacentă.

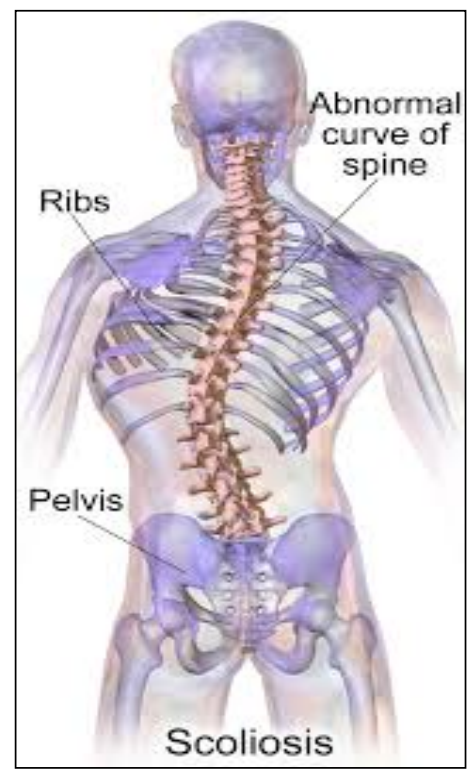

Figure 1. Scolioza

(Wikipedia, 2015. July)

Specialiștii domeniului fac referire la cauzele musculare ale modificărilor curburilor fiziologice și rolul deosebit al susținerii echilibrate a coloanei vertebrale.

Fiecare lanţ cinematic este alcătuit din mai multe grupe musculare, constituindu-se astfel lanţuri musculare. Întrucât majoritatea mişcărilor omului sunt mişcări complexe, în realizarea acestora sunt mobilizate mai multe grupe musculare cu acţiune sinergică sau antagonistă şi cupluri cinematice.

Spre exemplu, în mişcarea braţului de aruncare a mingii de baschet la coş, lanţul cinematic este format din - flexorii degetelor, flexorii pumnului, extensorii cotului, anteductorii braţului, ridicătorii şi muşchii care basculează scapula lateral. 


\section{Rezultate și discuții}

Pentru o mai bună înțelgere a modului de folosire a procedeului din baschet în corectarea unei atitudini scoliotice, vom prezenta analiza biomecanică a aruncării la coș, de pe loc, cu o mână de deasupra capului.

Acest procedeu de aruncare îmbină efortul static cu cel dinamic (Fig. 2).

Efortul static este realizat de către musculatura antagonistă (lanţurile musculare ale membrelor inferioare şi ale trunchiului prin efort de echilibrare) și de muşchii şanţurilor vertebrale (tripla extensie de la nivelul membrelor inferioare).

Efortul dinamic constă din extensia coordonată şi dozată a membrelor inferioare şi superioare, mişcarea fiind asigurată de: flexorii degetelor, flexorii pumnului, extensorii cotului, anteductorii braţului, ridicătorii şi muşchii care basculează scapula lateral. Este o mişcare de tip învingere; după aruncare efortul muscular dinamic se schimbă în activitate dinamică de cedare, care asigură în mod elastic poziţia constituind, în acelaşi timp, o bază pentru mişcarile care urmează (Făgăraș, 2015).

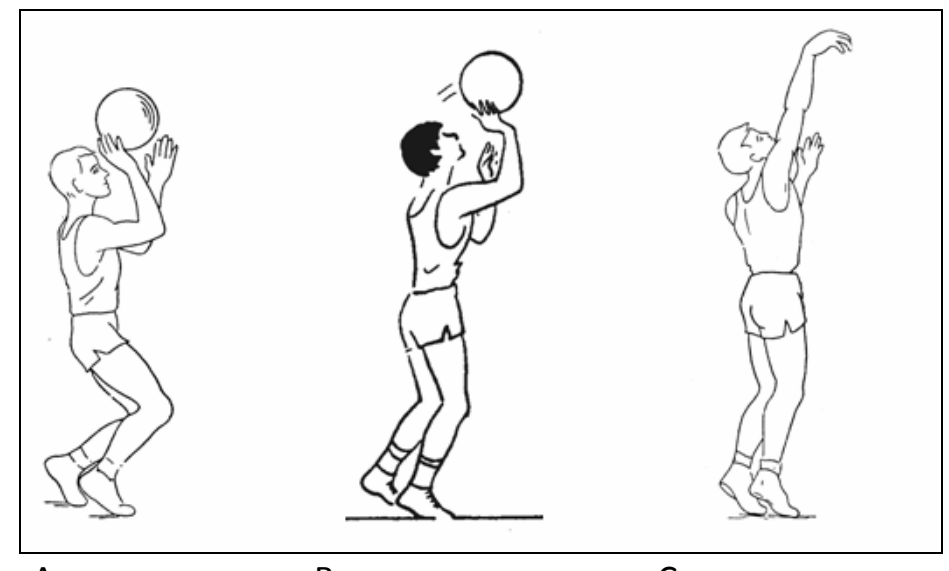

A.

B.

C.

Figure 2. A. Poziția inițială; B. Poziția intermediară; C. Poziția finală

Cunoașterea biomecanicii aruncării la cos cu o mână, de pe loc, ne îndreptățește să credem că aceasta poate fi inclusă în programele de prevenire/recuperare a atitudinilor scoliotice. Astfel, în cazul unei atitudini scoliotice pe partea stângă, prin mișcarea de triplă extensie de la nivelul membrelor inferioare (articulația gleznei, articulația genunchiului și articulația coxo-femurală), realizată concomitent cu întinderea brațului de aruncare, se produce creșterea mobilității mușchilor paravertebrali din partea concavității (în sensul întinderii acestora) și a scurtării mușchilor paravertebrali din partea convexității.

Program de intervenție propus pentru prevenirea/corectarea atitudinilor scoliotice și a scoliozei: 
1. Stând în partea dreaptă a coșului de baschet $(1,5 \mathrm{~m})$, la un unghi de $45^{0}$ față de coș, genunchii ușor îndoiți - extensie la nivelul membrelor inferioare, concomitent cu aruncarea mingii la coș, de pe loc, cu mâna dreaptă.

2. Stând în partea stângă a coșului de baschet $(1,5 \mathrm{~m})$, la un unghi de $45^{0}$ față de coș, genunchii ușor îndoiți - extensie la nivelul membrelor inferioare, concomitent cu aruncarea mingii la coș, de pe loc, cu mâna stângă.

3. Stând în partea dreaptă a coșului de baschet $(1,5 \mathrm{~m})$, la un unghi de $45^{0}$ față de coș, mingea de baschet este ținută pe palma dreaptă, mâna stângă este îndoită la spate, genunchii ușor îndoiți - extensie la nivelul membrelor inferioare, concomitent cu aruncarea mingii la coș, de pe loc, cu mâna dreaptă.

4. Stând în partea stângă a coșului de baschet $(1,5 \mathrm{~m})$, la un unghi de $45^{0}$ față de coș, mingea de baschet este ținută pe palma stângă, mâna dreaptă este îndoită la spate, genunchii ușor îndoiți - extensie la nivelul membrelor inferioare, concomitent cu aruncarea mingii la coș, de pe loc, cu mâna dreaptă.

5. Stând în partea dreaptă a coşului de baschet $(1,5 \mathrm{~m})$, la un unghi de $45^{0}$ față de coș, mingea de baschet este ținută pe palma dreaptă, piciorul stâng (de partea convexitătii) este sprijinit îndoit pe o bancă, mâna stângă este îndoită la spate, genunchii ușor îndoiți - extensie la nivelul membrelor inferioare, concomitent cu aruncarea mingii la coș, de pe loc, cu mâna dreaptă.

\section{Discuții}

Lipsa activității fizice, tehnologizarea și folosirea excesivă a calculatorului de către tineri, conduc la apariţia unor atitudini posturale deficitare. Cel mai des întâlnite în rândul tinerilor se numară atitudinile scoliotice.

Practicarea programelor kinetice și conştientizarea acestora de către tinerii cu atitudini scoliotice sunt de multe ori anevoioase, intervenind monotonia. Acest lucru, obligă specialiștii în domeniu la diversificarea programelor kinetice, folosind mijloace asociate, cum ar fi cele specifice unor ramuri sportive (baschetul).

Există numeroase studii care atestă influența activităților sportive asupra scoliozei la diferite vârste.

McMaster, Lee, and Burwell (2006) au efectuat un studiu pentru evaluarea activităților fizice ale pacienților cu scolioza idiopatică progresivă, iar rezultatele obținute le-au comparat cu cele ale unui grup de control. În urma studiului, s-a remarcat că scolioza idiopatică progresivă este asociată pozitiv cu înotul și negativ cu participarea la dans, patinaj, gimnastică, karate și cursuri de călărie.

În țările europene, există o preocupare majoră pentru detectarea timpurie a atitudinilor posturale deficitare. Astfel, în Rusia, copiii cu afecțiuni ale coloanei vertebrale sunt incluși în clase speciale de gimnastică medicală. În Germania se includ două ore suplimentare, săptămânal, pentru efectuarea exercițiilor corective sub îndrumarea unui kinetoterapeut. (Mitova, Popova \& Gramatikova, 2014)

Razumeiko (2015) consideră că pentru asigurarea diagnosticării și organizării timpurii a măsurilor preventive corective, este necesară monitorizarea permanentă a stării fizice și a capacității fizice a tinerilor. 
Jandrić (2015) este de părere că ar trebui evitate sporturile care antrenează musculatura unilaterală și asimetrică, cum ar fi: vâslitul, scrima, tenisul și disciplinele atletice (aruncarea suliței, ciocanului). Activităţile sportive și participarea la orele de educație fizică și sportivă sunt permise tinerilor cu atitudine scoliotică, dublate de realizarea unor programe kinetice specifice pentru a preveni agravarea atitudinii posturale deficitare.

În ceea ce privește influența unor sporturi de echipă (baschetul) asupra atitudinilor scoliotice, Puzović et al. (2015) susțin că este greu de spus dacă baschetul poate avea un efect pozitiv asupra scoliozei la copii și tineri, deoarece există puține dovezi că mijloacele baschetului sunt benefice în tratamentul subiecților cu atitudine scoliotică.

Societatea Științifică Internațională privind tratamentul scoliozelor nu recomandă activități sportive pentru subiecții diagnosticați cu scolioaza idipopatică. În schimb, sunt recomandate activitățile sportive pentru orice tip de atitudine posturală deficitară, datorită efectelor lor utile în plan psihologic, neuromuscular și al sănătăţii, în general. (Jandrić, 2015)

Cercetările menționate nu rezolvă complet problema profilaxiei și tratamentului scoliozelor prin intermediul activităților sportive. Astfel, este necesar să se continue cercetările interdisciplinare pentru găsirea celor mai bune soluții în vederea profilaxiei tulburărilor de postură și aliniament.

Considerăm că prezenta lucrare deschide noi direcții de cercetare, cu valoare aplicativă, prin elaborarea unor modele bazate pe mijloacele specifice jocului de baschet, în vederea îmbunătăţirii stării de sănătate a tinerilor.

\section{Concluzii}

Procedeele tehnice jocului de baschet, privite ca mijloace asociate kinetoterapiei, reprezintă un mod inovativ de abordare a prevenției posturale.

Aruncarea la coș este un element tehnic fundamental al jocului de baschet, care poate fi folosit cu succes în programele kinetice.

Descrierea din punct de vedere biomecanic a atitudinii scoliotice, ne-a elucidat asupra principaleleor aspecte privind modificările apărute la nivelul coloanei vertebrale.

Se constată asimetria tonusului muscular din partea convexităţii şi concavităţii malformaţiei. Mobilitatea muşchilor paravertebrali din partea concavă a deformaţiei este mai redusă, în comparaţie cu cea convexă. De asemenea, ca rezultat al modificărilor menţionate cutia toracică se micşorează în plan vertical şi se măreşte în plan orizontal.

Baschetul, privit ca mijloc asociat al kinetoterapiei și practicat în scop profilactic, trebuie dublat şi de alte măsuri profilactice: combaterea sedentarismului şi promovarea unei alimentații sănătoase. 